\title{
Hjelp oss med høye stoler
}

Jeg har nettopp byttet hofteprotese. Erfaringene fra sykehus, rehabiliteringssenter og legesentre er at det ikke finnes høye stoler på disse stedene. Det må det gjøres noe med.

Jeg lå fire timer på operasjonsbordet og tilbrakte fire uker på sykehus, to ved ortopedisk avdeling Ullevål og to ved rehabiliteringsavdeling Aker. Men det fantes ikke en eneste høy stol på oppholdsrommet på Aker, så der kunne jeg ikke sette meg ned.

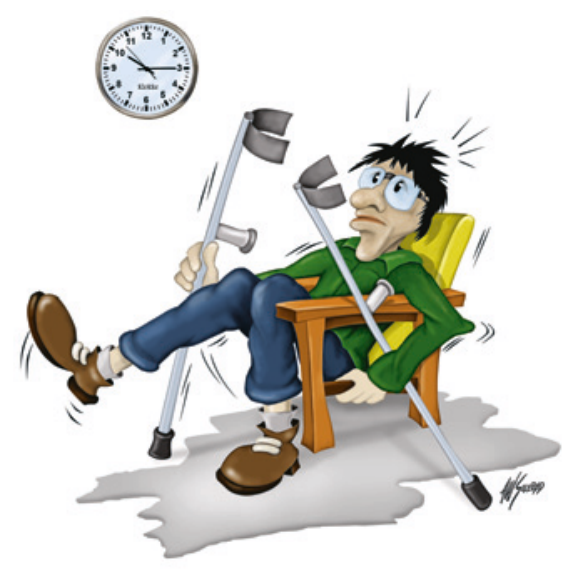

Illustrasjon: Arild Walberg Solerød
Ved avreise ble det bestilt høy taxi. Både den første og den andre som kom, måtte sendes tilbake grunnet for lave seter. Avdelingen skaffet deretter den tredje bilen, som jeg lett kom meg inn i. Da hadde jeg ventet over en time. Heller ikke i mottaket fantes det en høy stol, så ventetiden ble lang.

Jeg vil takke leger, sykepleiere og fysioterapeuter for god behandling. Vanligvis er det ikke noen fra disse yrkesgruppene som kjøper inn stoler. Men kanskje dere kan hjelpe oss og bringe behovet for høye stoler videre til administrasjonen, til dem som steller med innkjøp, sannsynligvis mennesker uten proteseerfaring?

Fysioterapeutene ber oss huske på å sitte på høye stoler de tre første månedene etter å ha fått satt inn protese. Det er vanskelig når det ikke finnes slike stoler tilgjengelig. Det vil glede oss over 60 med vonde knær og hofter, med eller uten proteser, hvis høye stoler etter hvert blir en del av inventaret i de offentlige rommene.
Årlig opereres det inn omtrent 7000 hofteproteser, kunstige hofteledd, og omtrent 5000 kneproteser på landsbasis. Vi er mange med samme hverdagsutfordring, så bring stafettpinnen videre, slik at vi får sitte både riktig og godt på sykehuset, hos fastlegen, hos fysioterapeuten og på apoteket.

\section{Per Storås \\ pstoras42@gmail.com}

Per Storås (f. 1942) er pensjonist.

Forfatter har fylt ut ICMJE-skjemaet og oppgir ingen interessekonflikter.

Mottatt 21.1. 2015 og godkjent 11.2. 2015. Redaktør: Erlend Hem.

Publisert først på nett. 